\title{
Determination of Nutritional Quality and Aerobic Stability of Sorghum, Maize, and Sorghum-Maize Mixture Silages
}

Sorgum, Mısır ve Sorgum-Mısır Karışımı Silajlarının Besin Kalitesi ve Aerobik Stabilitesinin Belirlenmesi

\section{Selim ESEN ${ }^{*}$, Berrin OKUYUCU ${ }^{2}$, Fisun KOÇ ${ }^{3}$, Mehmet Levent ÖZDÜVEN ${ }^{4}$}

\begin{abstract}
The current study aimed to determine the nutritional quality and aerobic stability of sorghum, maize, and their mixture silages without any additives. Sorghum and maize were harvested at dough stage from a local farm in Tekirdağ. Fresh plant materials were chopped to a length of $2-3 \mathrm{~cm}$ and packed into polythene bags, and vacuumed. A total of 12 vacuum-packed silos (4 replications in each treatment) were prepared with sorghum (S), maize (M), and a mixture of sorghum-maize (SM) forage (w:w, 50:50 according to dry matter) and stored at room temperature for 60 days. The chemical and microbiological composition of silages with the rate of aerobic deterioration upon aerobic exposure were evaluated. Based on the $\mathrm{pH}$ and ammonia nitrogen concentration, all silages could be classified as good quality. The water-soluble carbohydrate level of the SM group increased due to mixing S and $\mathrm{M}$ forages, leading to improved lactic acid content. The NDF and ADF values of silages varied between 520.52588.32 and $234.98-309.01 \mathrm{~g} \mathrm{~kg}^{-1}$, and the differences between silages were significant $(\mathrm{P}<0.01)$. The Hemicellulose/Cellulose ratio of S, M, and SM silages were found $0.94,1.49$, and 1.18, respectively. The lactobacilli and yeast content of silages were significant and varied between 5.18-7.41 and 5.18-7.29 $\log \mathrm{cfu} \mathrm{g}^{-1}$, and the highest and lowest values were observed in SM and $\mathrm{S}$ silages, respectively $(\mathrm{P}<0.01)$. No visible mold was detected in all silages after 5 days of aerobic exposure $(\mathrm{P}>0.05)$. The $\mathrm{pH}, \mathrm{CO}_{2}$, and yeast numbers were varied in groups between 4.88-6.74, 55.71-119.33 $\mathrm{g} \mathrm{kg}^{-1}$, and 8.40-9.01 $\log \mathrm{cfu} \mathrm{g}^{-1}$. It was concluded that it is possible to improve the nutritional and fermentation characteristics of sorghum and maize silage by ensiling their mixture. However, it is highly recommended that silage additives should be used to guarantee and strengthen the fermentation and aerobic stability of silage mostly made by a mixture of these two energetic forage crops.
\end{abstract}

Keywords: Sorghum, Maize, Silage, Aerobic stability, Silage quality

\footnotetext{
1*Sorumlu Yazar/Corresponding Author: Selim Esen, Balikesir Directorate of Provincial Agriculture and Forestry, Republic of Turkey Ministry of Agriculture and Forestry, Manyas, Balikesir, Turkey. E-mail: selim esen01@hotmail.com (iD) OrcID: 0000-0003-4953-7960

${ }^{2}$ Berrin Okuyucu, Tekirdağ Namık Kemal University, Faculty of Agriculture, Department of Animal Science, Tekirdağ, Turkey. E-mail: berrinokuyucu25@hotmail.com (D) OrcID: 0000-0001-8322-5050

${ }^{3}$ Fisun Koç, Tekirdağ Namık Kemal University, Faculty of Agriculture, Department of Animal Science, Tekirdağ, Turkey. E-mail: fkoc@nku.edu.tr 10 OrcID: 0000-0002-5978-9232

${ }^{4}$ Mehmet Levent Özdüven, Tekirdağ Namık Kemal University, Faculty of Agriculture, Department of Animal Science, Tekirdağ, Turkey. E-mail: lozduven@nku.edu.tr (D) OrcID: 0000-0002-8951-8054

Atıf/Citation: Esen, S., Okuyucu, B., Koç, F., Özdüven, M.L. Deterrmination of Nutritional Quality and Aerobic Stability of Sorghum, Maize, and Sorghum-Maize Mixture Silages. Tekirdağ Ziraat Fakültesi Dergisi, 19 (1), 61-69.

(CBu çalışma Tekirdağ Namık Kemal Üniversitesi tarafından Creative Commons Lisansı (https://creativecommons.org/licenses/by-nc/4.0/) kapsamında yayınlanmıştır. Tekirdağ 2022 


\section{$\ddot{\mathbf{O} z}$}

Bu çalışmada, katkı maddesi içermeyen sorgum, mısır ve bunların karışımından oluşan silajların silaj kaliteleri ve aerobik stabilite özelliklerinin belirlenmesi amaçlanmıştır. Sorgum ve mısır hamur olum döneminde Tekirdağ'daki lokal bir işletmeden temin edilmiştir. Taze bitki materyalleri $2-3 \mathrm{~cm}$ uzunlunda doğranarak ve polietilen torbalara konulmuş ve vakumlanmıştır. Sorgum (S), mısır (M) ve sorgum-mısır karışımından (kuru madde düzeyine göre 50:50) her bir muamele grubu için 4 tekerrür olmak üzere toplamda 12 adet vakumlanmış paket silo hazırlanmış ve oda sıcaklığında 60 gün silolanmıştır. Silajların kimyasal ve mikrobiyolojik kompozisyonları ile oksijene maruz kalması sonrası aerobik bozulma oranları birlikte değerlendirilmiş̧tir. Elde edilen $\mathrm{pH}$ ve amonyak nitrojen konsantrasyonuna göre tüm silajlar iyi kaliteli sınıfında yer almıştır. S ve M'nin karışımından oluşan SM grubunda, suda çözünebilir karbonhidrat oranının artması laktik asit içeriğinin artmasını sağlamıştır. Silajların NDF ve ADF içeriğindeki farklar önemli olmakla birlikte sırasıyla 520.52-588.32 ve 234.98-309.01 $\mathrm{g} \mathrm{kg}^{-1}$ arasında değişim göstemiştir $(\mathrm{P}<0.01)$. Hemiselüloz/selüloz oranı $\mathrm{S}, \mathrm{M}$ ve $\mathrm{SM}$ gruplarında sirasıyla $0.94,1.49$ ve 1.18 olarak bulunmuştur. Silajların laktobasil ve maya içerikleri arasındaki farklar önemli olup 5.17-7.41 ve 5.18-7.29 log kob $\mathrm{g}^{-1}$ arasında değişiklik göstermiş ve en yüksek ile en düşük değerler sırasıyla SM ve S silajlarında gözlemlenmiştir $(\mathrm{P}<0.01)$. Beş günlük aerobik maruziyet sonrasında tüm silaj gruplarında küf tespit edilmemiştir $(\mathrm{P}>0.05)$. Silaj gruplarında $\mathrm{pH}, \mathrm{CO}_{2}$ ve maya sayısı sirasıyla 4.88-6.74, 55.71-119.33 $\mathrm{g} \mathrm{kg}^{-1}$ ve 8.40-.01 log kob g ${ }^{-1}$ arasinda değişmiştir. Sorgum ve mısırın birlikte silolanması ile besin ve fermantasyon kalitesini iyileştirmenin mümkün olduğu sonucuna varılmıştır. Bununla birlikte enerji bakımından zengin bu iki bitkinin birlikte silolanmasını garanti altına almak ve fermentasyon ve aerobic stabilitesini güçlendirmek amaciyla katkı maddelerinin kullanılması önerilmektedir.

Anahtar Kelimeler: Sorgum, Misır, Silaj, Aerobik stabilite, Silaj kalitesi 


\section{Introduction}

Supplying high-quality roughage to livestock year-round results in high milk and meat production. Meeting these animals' nutrient demands with high-quality roughage in dry seasons and preserving them from deterioration in the rainy seasons is among the most crucial constraint for livestock production. To overcome this constraint, the crop-livestock integration system intercorporate two types of annual grasses; one is forage to provide feed for livestock from late summer to early spring, and the other is a grain-producing crop to provide straw (Nakao et al., 2018). Although Turkey's ecological conditions allow the cultivation of many forage crops being suitable for silage production, maize and sorghum species and their hybrids are the most cultivated ones (Demirel et al., 2003).

Maize's popularity is derived from its high yielding potential, high energy concentration, palatability, and easy application in the total mixed ration and it's all forms (e.g., grain, hay, silage) represent a principal and essential feed source for farm animals on a global scale (Szymańska et al., 2014). Feed produced from maize is also characterized by relatively low nitrogenous content and biological value (Daniel et al., 2008). Therefore, it should be used together with other roughage and concentrated feed.

Sorghum (Sorghum bicolor L. Moench) is characterized by drought resistance and salinity tolerance, high water-soluble carbohydrates, and greater biomass yield than maize (Rocateli et al.,2012; Pinho et al., 2015). Moreover, dual-purpose sorghum hybrids can reach $68 \%$ more dry matter (DM) yield than wild ones due to their number of panicles (Da Silva et al., 2012). The nutritional quality of sorghum is influenced by the genotype, specific size, life cycle, and breeding purpose is classified into four main groups according to their stem, number of panicles, and stem-leaf ratio:grain, forage, grazing, and broom (Neto et al., 2017; Perazzo et al., 2014). In addition to these factors, plant height, maturity stage at harvest, chopt length, and additives also influence sorghum's nutritional quality of ensiling (Zurak et al., 2018; Da Silva et al., 2012). It was stated in the literature that some sorghum varieties did not meet the nitrogen requirements of ruminants when fed without a concentratefree diet and resulted in insufficient total digestible nutrients (Kaewpila et al., 2021). The cell wall components of sorghum silages (ADF and ADL content) decrease ruminants' acceptance rate and reduce forage digestibility (Thomas, 2013).

On the other hand, sorghum's production cost is lower than maize in a single seeding with more than one cut, and the nutritional quality is $10-15 \%$ lower than maize (Carvalho et al., 2016). Also, sorghum's high moisture content and thick stem structure make it more suitable for ensiling than hay production (Liang et al., 2018). One main challenge to make a good quality sorghum silage is that its low DM content. It is possible to increase the DM content of sorghum ensiling with maize without any preservatives. Therefore, this study aimed to investigate the fermentation and nutritional quality, and aerobic stability of sorghum (S), maize (M), and sorghum-maize mixture (SM) silages without any preservatives.

\section{Materials and Methods}

Sorghum cultivar of ES Hyperion (Euralis) and maize hybrid of BC 678 (BC Institut) were harvested at dough stage from a local farm in Tekirdağ in 2019, and then study material was immediately transferred into the Animal Feed and Nutrition Laboratory of Tekirdag Namık Kemal University for silage preparation and further analysis. The total precipitation and average temperature of the experimental year were $299.0 \mathrm{~mm}$ and $15.7^{\circ} \mathrm{C}$, respectively. Since the total precipitation was not sufficient, forage water demands were supplied by irrigation fortnightly (Figure 1).

At the laboratory, fresh plant materials were chopped to a length of 2-3 $\mathrm{cm}$ and packed into polythene bags, and sealed by a vacuum sealer (CAS CVP-260PD) (Tan, 2021; Büyüktosun and Tan, 2015). A total of 12 vacuumpacked silos (4 replications in each treatment) were prepared with sorghum, maize, and a mixture of sorghummaize forage (w:w, 50:50 according to DM) stored. The chemical and microbiological composition of S, M, and SM ensiling was given in Table 1. 


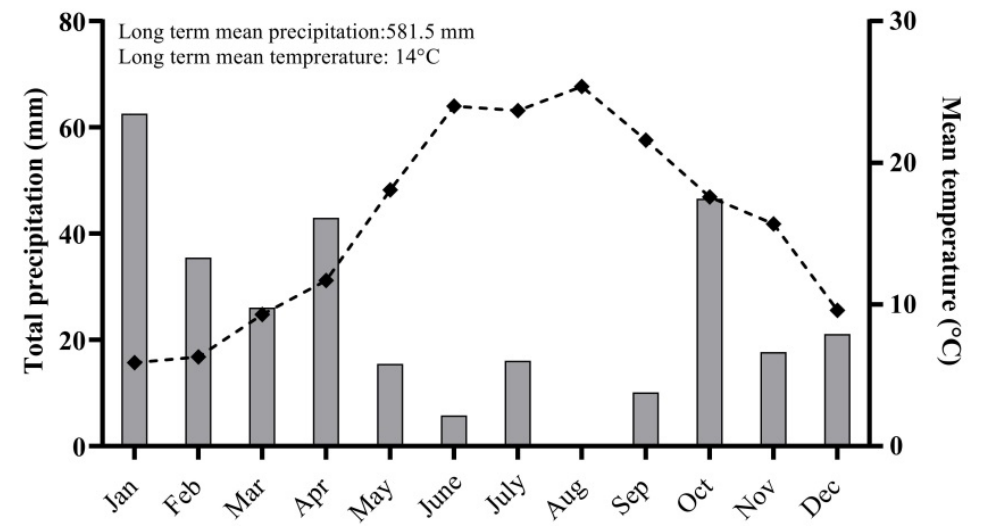

Figure 1. Monthly total precipitation and mean temperature in 2019 at Tekirdag, Turkey.

The vacuum-packed silos were opened at the end of 60 days of ensiling, and $\mathrm{pH}, \mathrm{DM}$, WSC and lactic acid content of silages were determined immediately (Anonymous, 1986; Chen et al., 1994; Koç and Çoşkuntuna, 2003). The ammonia nitrogen $\left(\mathrm{NH}_{3}-\mathrm{N}\right)$ content of silages was carried using the micro distillation method (Anonymous, 1986). Aerobic stability test in bottle systems for 5 days described by Asbell et al. (1991) was subjected simultaneously. At the end of the aerobic stability test, change in $\mathrm{pH}$, production of carbon dioxide $\left(\mathrm{CO}_{2}\right)$, number of yeast and mold were used as an indicator. Enumeration of LAB, yeast, and mold of silages was determined using MRS (de Man, Rogosa and Sharpe) and potato dextrose agar, according to Seale et al. (1990) and presented on fresh and wet silages basis.

Table 1. Chemical and microbiological composition of starting materials

\begin{tabular}{|c|c|c|c|}
\hline Item & $\mathbf{S}$ & $\mathbf{M}$ & SM \\
\hline $\mathrm{DM}, \mathrm{g} \mathrm{kg}^{-1}$ & 250.2 & 330.0 & 283.2 \\
\hline $\mathrm{pH}$ & 5.8 & 6.0 & 6.3 \\
\hline $\mathrm{CP}, \mathrm{g} \mathrm{kg}^{-1} \mathrm{DM}$ & 80.02 & 61.10 & 72.85 \\
\hline WSC, $\mathrm{g} \mathrm{kg}^{-1} \mathrm{DM}$ & 122.0 & 135.7 & 130.0 \\
\hline Lactobacilli, $\log 10$ cfu $g^{-1}$ & 2.18 & 3.00 & 2.78 \\
\hline Yeast, $\log 10 c f u g^{-1}$ & 5.18 & 6.90 & 6.10 \\
\hline Mould, $\log 10 \mathrm{cfu} \mathrm{g}^{-1}$ & $<10$ & $<10$ & $<10$ \\
\hline
\end{tabular}

The proximate analysis of fresh material and silages was performed according to AOAC (1990). The Neutral detergent fiber (NDF), acid detergent fiber (ADF), and acid detergent lignin (ADL) of silages was determined according to Van Soest et al. (1991).

The digestible dry matter (DDM) and dry matter intake (DMI) of silages were calculated using NDF and ADF values by the given equations below (Moore and Undersander, 2002). Then DDM and DMI values were used to calculate the relative feed value (RFV) of silages by the following equations $(1,2,3)$ developed by Van Dyke and Anderson (2002).

$$
\begin{aligned}
& D D M(\%)=88.9-0.779 \times A D F \\
& D M I(\%)=120 \div N D F \\
& R F V=D D M \times D M I \times 0.775
\end{aligned}
$$

The effect of treatments on fermentation quality and nutritive value of silages were analyzed using the GLM procedure of Minitab (2014) statistical package programs, and least-squares means were compared using Tukey's multiple comparison tests. The following statistical model (Eq.4) was used:

$y_{i j}=\mu+a_{j}+e_{i j}$

Where $y_{i j}=$ observed value; $\mu=$ overall mean; $a_{i}=$ effect of treatment; $e_{i j}=$ effect of the experimental error. 


\section{Results and Discussion}

An adequate level of DM, WSC, and buffering capacity (BC) of ensiled plant material is required to achieve good quality silage, and it was stated in the previous studies that the DM content of ensiled plant material is desired to be around 300-350 $\mathrm{g} \mathrm{kg}^{-1}$ to ensure sufficient fermentation in the silo (Neto et al., 2017). A desirable WSC level is also required for a rapid decrease in $\mathrm{pH}$ at the initial phase of the fermentation and produces more lactic acid bacteria (LAB) to protect silage microflora against spoilage (Başkavak et al., 2008). The silo's fermentation is often checked with the measuring $\mathrm{pH}$ and $\mathrm{NH}_{3}-\mathrm{N}$ level due to its practical application. Kaya and Polat (2010) have classified the silages within the $\mathrm{pH}$ range between 3.7-4.2 as good quality. Also, Veriato et al. (2018) considered the silages as very good $\left(<100 \mathrm{~g} \mathrm{~kg}^{-1}\right)$, good $\left(100-150 \mathrm{~g} \mathrm{~kg}^{-1)}\right.$, medium $\left(150-200 \mathrm{~g} \mathrm{~kg}^{-1}\right)$, and bad $\left(>200 \mathrm{~g} \mathrm{~kg}^{-1}\right)$ quality according to their $\mathrm{NH}_{3}-\mathrm{N}$ content. The DM and WSC content of fresh S, M, and SM silage was 250.2, 330.0 , and $283.2 \mathrm{~g} \mathrm{~kg}^{-1} ; 122.0,135.7$, and $130.0 \mathrm{~g} \mathrm{~kg}^{-1}$, respectively (Table 1). Considering the WSC, the levels observed in this investigation are lower than those reported by Neto et al. (2017) but higher than Alhaag et al. (2019).

The $\mathrm{pH}$ of silages was significant $(\mathrm{P}<0.05)$ and below 4.2, which means all silages could be classified as good quality dealing with obtained values. The highest (4.13) and the lowest (3.90) $\mathrm{pH}$ values were observed in the SM and $\mathrm{S}$ groups. The $\mathrm{DM}$ of silages was found significant $(\mathrm{P}<0.01)$ in the present study. Also, the differences among the silage groups in $\mathrm{NH}_{3}-\mathrm{N}$ content were significant $(\mathrm{P}<0.01)$; all silages could be classified as good quality $\left(\mathrm{NH}_{3}-\right.$ $\mathrm{N}<100 \mathrm{~g} \mathrm{~kg}^{-1} \mathrm{TN}$ ). The $\mathrm{NH}_{3}-\mathrm{N}$ parameter is also used to determine the level of proteolysis in silages. The $\mathrm{NH}_{3}-\mathrm{N}$ is mainly derived from amino acid catabolism and degradation products of some biochemical processes such as deamination, decarboxylation, and oxidation and reductions, resulting in heating in the silo mass (Veriato et al., 2018). In contrast, well-preserved silages with low proteolytic activity may improve microbial protein synthesis in the rumen (Sucu et al., 2016).

In the current study, the $\mathrm{S}$ group's LA content was recorded significantly higher than the M and MS groups $(\mathrm{P}<0.01)$. It was also suggested that the LA content of silages must be greater than $20 \mathrm{~g} \mathrm{~kg}^{-1}$ to yield good quality silages (Kaya and Polat, 2010). The WSC content of pre-ensiled material also affects the lactic acid (LA) content of silages. In general, high WSC may induce more LA production during ensiling. The WSC of the SM group was increased due to mixing $\mathrm{S}$ and $\mathrm{M}$ forages, leading to improved LA content (Table 2). The results derived from this study were in agreement with the findings of Kaplan (2013) and Pinho et al. (2015), who stated increased level of WSC enhanced the LA content of silage and accounted for a lower $\mathrm{pH}$ value.

Table 2. Fermentation quality and chemical composition of silages

\begin{tabular}{lcccc} 
& \multicolumn{3}{c}{ Treatments } & \\
\cline { 2 - 4 } Item & $\mathbf{S}$ & $\mathbf{M}$ & $\mathbf{S M}$ & P \\
\hline DM & $247.05 \pm 7.06^{\mathbf{c}}$ & $328.72 \pm 9.73^{\mathbf{a}}$ & $275.31 \pm 1.93^{\mathbf{b}}$ & $* *$ \\
pH & $3.90 \pm 0.02^{\mathbf{b}}$ & $4.05 \pm 0.01^{\mathbf{a b}}$ & $4.13 \pm 0.14^{\mathbf{a}}$ & $*$ \\
CP & $75.44 \pm 2.91^{\mathbf{a}}$ & $60.72 \pm 1.46^{\mathbf{c}}$ & $69.46 \pm 1.17^{\mathbf{b}}$ & $* *$ \\
Ash & $67.34 \pm 0.60^{\mathbf{a}}$ & $35.84 \pm 2.85^{\mathbf{c}}$ & $52.45 \pm 0.84^{\mathbf{b}}$ & $* *$ \\
NDF & $554.43 \pm 3.92^{\mathbf{b}}$ & $520.52 \pm 4.02^{\mathbf{c}}$ & $588.32 \pm 10.19^{\mathbf{a}}$ & $* *$ \\
ADF & $309.01 \pm 12.03^{\mathbf{a}}$ & $234.98 \pm 4.33^{\mathbf{b}}$ & $294.57 \pm 2.56^{\mathbf{a}}$ & $* *$ \\
ADL & $47.32 \pm 3.20$ & $42.80 \pm 2.44$ & $46.61 \pm 3.67$ & $\mathrm{NS}$ \\
Hcell & $245.41 \pm 15.63^{\mathbf{b}}$ & $285.53 \pm 8.26^{\mathbf{a}}$ & $293.75 \pm 10.64^{\mathbf{a}}$ & $*$ \\
Cell & $261.69 \pm 9.04^{\mathbf{a}}$ & $192.18 \pm 2.99^{\mathbf{c}}$ & $247.96 \pm 6.13^{\mathbf{b}}$ & $* *$ \\
WSC & $15.35 \pm 0.82^{\mathbf{a}}$ & $2.95 \pm 0.16^{\mathbf{c}}$ & $4.41 \pm 0.32^{\mathbf{b}}$ & $* *$ \\
NH3-N & $86.24 \pm 2.18^{\mathbf{a}}$ & $74.97 \pm 2.94^{\mathbf{b}}$ & $85.82 \pm 2.10^{\mathbf{a}}$ & $* *$ \\
LA & $39.54 \pm 8.84^{\mathbf{a}}$ & $12.02 \pm 2.54^{\mathbf{b}}$ & $19.29 \pm 1.00^{\mathbf{b}}$ & $* *$ \\
RFV & $108.74 \pm 0.95^{\mathbf{b}}$ & $126.13 \pm 0.43^{\mathbf{a}}$ & $104.28 \pm 1.83^{\mathbf{c}}$ & $* *$ \\
DDM & $64.83 \pm 0.94^{\mathbf{b}}$ & $70.60 \pm 0.34^{\mathbf{a}}$ & $65.95 \pm 0.20^{\mathbf{b}}$ & $* *$ \\
DMI & $2.16 \pm 0.02^{\mathbf{b}}$ & $2.31 \pm 0.02^{\mathbf{a}}$ & $2.04 \pm 0.04^{\mathbf{c}}$ & $* *$ \\
\hline
\end{tabular}

$\overline{a, b, c}$ Values within a row with different superscripts differ significantly at $\mathrm{P}<0.05$

DM: Dry Matter, $\mathrm{g} \mathrm{kg}^{-1}$; CP: Crude Protein, $\mathrm{g} \mathrm{kg}^{-1} \mathrm{DM}$; Ash, $\mathrm{g} \mathrm{kg}^{-} \mathrm{DM}$; NDF: Neutral Detergent Fiber, $\mathrm{g}$ $\mathrm{kg}^{-1} \mathrm{DM}$; ADF: Acid Detergent Fiber, $\mathrm{g} \mathrm{kg}^{-1} \mathrm{DM}$; ADL: Acid Detergent Lignin, $\mathrm{g} \mathrm{kg}^{-1} \mathrm{DM}$; Hcell: Hemicellulose, $\mathrm{g} \mathrm{kg}^{-1} \mathrm{DM}$; Cell: Cellulose, $\mathrm{g} \mathrm{kg}^{-1} \mathrm{DM}$; WSC: Water Soluble Carbohydrate, $\mathrm{g} \mathrm{kg}^{-1} ; \mathrm{NH}_{3}-\mathrm{N}$ : Ammonia Nitrogen, $\mathrm{g} \mathrm{kg}^{-1} \mathrm{TN}$; LA: Lactic Acid, $\mathrm{g} \mathrm{kg}^{-1} \mathrm{DM}$; RFV: Relative feed value; DDM: Digestible Dry Matter, \%; DMI: Dry Matter Intake, \%; NS: Not significant $(\mathrm{P}>0.05)$; *: $\mathrm{P}<0.05$; **: $\mathrm{P}<0.01$; ***: $\mathrm{P}<0.001$ 
Differences with respect to the CP and ash content among the silage groups were found significant $(\mathrm{P}<0.01)$. This result was expected because it was stated by some researchers in the earlier studies that the forage quality may strongly be affected by species, genotype, maturity at harvesting period, steam/leaf ratio, number of panicles (Cândido et al., 2002; Da Silva et al., 2012). The results were consistent with an adequate CP level for the functioning of ruminal microbiota (Pinho et al., 2015). Ash referring to mineral content in forages, influenced by maturity, is found higher in seed than those of other parts. The ash content of silages ranged between 35.84 to $67.84 \mathrm{~g} \mathrm{~kg}^{-1}$, and the differences among the treatments were significant $(\mathrm{P}<0.05)$. The obtained results were lower than the findings reported by Sucu et al. (2016) for M silage but higher than S silage. These results were also determined higher than the findings stated by Dundar et al. (2020) for S and SM silages.

The NDF and ADF values of silages, indicative of the amount of forage fiber, were varied between 520.52588.32 and 234.98-309.01 $\mathrm{g} \mathrm{kg}^{-1}$, and the differences among the silages in terms of NDF values were found significant $(\mathrm{P}<0.01)$. Some researchers reported that the level of NDF is above $600 \mathrm{~g} \mathrm{~kg}^{-1}$, NDF negatively affects the DM consumption of ruminants, if the ADF level is above $300 \mathrm{~g} \mathrm{~kg}^{-1}$, ADF hinders feed fragmentation and digestion by ruminal bacteria (Gonçalves et al., 2010; Veriato et al., 2018). Based on the obtained results, fiber levels of silage groups were close to those reported for sorghum and maize silages. On the other hand, the ADL content of silages did not differ in the groups $(\mathrm{P}<0.05)$. This situation may be derived from the harvesting of these crops at the same maturity stages. Several authors emphasized that the lignin content of forages increased with the advancement of the stage of maturity (Ferreira and Mertens, 2007; Gonçalves et al., 2010; Nurk et al., 2016).

Ruminants can benefit more from feeds with a high hemicellulose $\left(\mathrm{H}_{\text {cell }}\right) /$ cellulose $($ Cell $)$ ratio due to the easy degradation of $\mathrm{H}_{\text {cell }}$ than Cell. The $\mathrm{H}_{\text {cell }}$ and Cell values of silages were determined significant $(\mathrm{P}<0.05$ and $\mathrm{P}<0.01)$. In the present study, $\mathrm{H}_{\text {cell }} / \mathrm{Cell}$ ratios of $\mathrm{S}, \mathrm{M}$, and $\mathrm{SM}$ silages were found as $0.94,1.49$, and 1.18 , respectively. The results from this study for S silage were lower than the findings of Veriato et al. (2018), who evaluated the seventeen S genotypes but higher than those noted by Dundar et al. (2020), who applied different irrigation levels for ensiled material.

The differences in terms of RVF, DDM, and DMI between among the silage groups were significant $(\mathrm{P}<0.01)$. While the M silages had the highest values, the SM silages showed the lowest value (except for DDM in S silages). Based on the results from the present study, S (108.74) and SM (104.28) silages were categorized in the second quality class, while the $\mathrm{M}$ (126.13) silages were evaluated in the first class according to legume, grass, or mixed hay quality standards developed by American Forage and Grassland Council (Kaplan et al., 2014). Similar RFV values of forage $S$ and $M$ were also stated by Neves et al. (2015) and Kızılşimşek et al. (2020).

Kaewpila et al. (2021) indicated that to promote lactic acid fermentation, the fresh form of ensiling material must include at least $5 \log$ cfu g ${ }^{-1}$ epiphytic bacteria. Otherwise, harmful bacteria should not be controlled during the ensiling period without any silage additives. In this study, the number of epiphytic bacteria was smaller than the recommended values. The microbiological composition of silages was presented in Table 3. After 60 days of the ensiling period, the number of lactobacilli and yeast content was significant among the silage groups $(\mathrm{P}<0.01)$.

Table 3. Microbiological composition of silages

\begin{tabular}{lcccc}
\hline & \multicolumn{3}{c}{ Treatments } & \\
\cline { 2 - 4 } Item & $\mathbf{S}$ & $\mathbf{M}$ & SM & P \\
\hline${\text { Lactobacilli, } \log c f u g^{-1}}$ & $5.18 \pm 0.16^{\mathbf{c}}$ & $6.04 \pm 0.74^{\mathbf{b}}$ & $7.41 \pm 0.15^{\mathbf{a}}$ & $* *$ \\
Yeast, $\log c f u g^{-1}$ & $5.18 \pm 0.17^{\mathbf{b}}$ & $5.73 \pm 0.81^{\mathbf{b}}$ & $7.29 \pm 0.12^{\mathbf{a}}$ & $* *$ \\
Mold, $\log c f u g^{-1}$ & $<10$ & $<10$ & $<10$ & NS \\
\hline a,b,c Means in the same row with different superscripts differ significantly at $\mathrm{P}<0.05$ & \\
NS: Not significant; $* *: \mathrm{P}<0.01$ & & &
\end{tabular}

Mixing S and M forages increased the number of lactobacilli and mold content of silages. The lactobacilli and yeast content of silages varied between 5.18-7.41 and 5.18-7.29 $\mathrm{log} \mathrm{cfu} \mathrm{g}^{-1}$ and the highest and lowest values were observed in SM and S silages, respectively. No mold growth was detected in all silage groups. It was observed that silages with a higher lactobacilli content were of a lower $\mathrm{pH}$ value compared to others. Inconsistent with this expectation, SM silages had the most elevated $\mathrm{pH}$ and lactobacilli content. It was attributed by Khota et al. (2017) to natural bacteria present in pre-ensiled material, which may produce a different amount of short-chain fatty acids 
during the fermentation process, and the interaction effect of $\mathrm{S}$ and $\mathrm{M}$ forages. Filya et al. (2004) reported that the lactobacilli number as 6.7 and 7.0, and yeast number as 5.8 and $5.5 \operatorname{log~cfu~} \mathrm{g}^{-1}$ in sorghum and maize silages ensiled for 60 days, respectively. Sucu et al. (2016) found similar results in a study that aimed to determine the effect of ensiling density on the nutritive value of $\mathrm{S}$ and $\mathrm{M}$ silages. The obtained results from this study were in consistent with the above reports mentioned by some researchers. The aerobic stability parameters of silages are given in Table 4. No visible mold was detected in all silages after 5 days of aerobic exposure $(\mathrm{P}>0.05)$.

Table 4. Aerobic stability parameters of silages

\begin{tabular}{|c|c|c|c|c|}
\hline \multirow[b]{2}{*}{ Item } & \multicolumn{3}{|c|}{ Treatments } & \multirow[b]{2}{*}{$\mathbf{P}$} \\
\hline & $\mathbf{S}$ & $\mathbf{M}$ & SM & \\
\hline $\mathrm{DM}, g \mathrm{~kg}^{-1}$ & $252.61 \pm 0.98^{c}$ & $342.60 \pm 7.24^{\mathrm{a}}$ & $283.91 \pm 3.24^{\mathbf{b}}$ & $* *$ \\
\hline $\mathrm{pH}$ & $4.88 \pm 0.25^{\mathrm{c}}$ & $6.74 \pm 0.03^{\mathrm{a}}$ & $6.35 \pm 0.01^{\mathbf{b}}$ & $* *$ \\
\hline $\mathrm{CO}_{2}, g \mathrm{~kg}^{-1} \mathrm{DM}$ & $55.71 \pm 9.93^{\mathbf{b}}$ & $118.78 \pm 5.07^{\mathrm{a}}$ & $119.33 \pm 0.98^{\mathbf{a}}$ & $* *$ \\
\hline Yeast, $\log c f u g^{-1}$ & $8.40 \pm 0.15^{\mathrm{c}}$ & $9.08 \pm 0.03^{\mathrm{a}}$ & $8.71 \pm 0.02^{\mathbf{b}}$ & $* *$ \\
\hline Mold, $\log c f u g^{-1}$ & $<10$ & $<10$ & $<10$ & NS \\
\hline
\end{tabular}

The $\mathrm{pH}, \mathrm{CO}_{2}$, and yeast numbers varied in silage groups between 4.88-6.74, 55.71-119.33 $\mathrm{g} \mathrm{kg}^{-1}$, and 8.40-9.01 $\log \mathrm{cfu}^{-1}$. Vissers et al. (2007) noted that to start the deterioration process, the $\mathrm{pH}$ and yeast numbers in silages must be above 5 and 7 after exposure to air, respectively. However, the differences among the silages with respect to $\mathrm{pH}, \mathrm{CO}_{2}$, and yeast numbers were significant $(\mathrm{P}<0.01)$ (Toruk et al., 2010). As seen in Table 4, the deterioration process appeared in all silage groups. Ruppel et al. (1995) reported that a decrease of exposed time of silages to air without spoiling before removal from the silo caused these results. On the other hand, one unexpected finding was the highest $\mathrm{CO}_{2}$ level $\left(119.33 \mathrm{~g} \mathrm{~kg}^{-1}\right)$ observed in SM silages. This unexpected result could be attributed to the acceleration of microbial activity at high $\mathrm{pH}$ and the increased risk of $\mathrm{O}_{2}$ due to negative gas pressure in the silo (Li et al., 2017).

\section{Conclusions}

In this study, fermentation and nutritional characteristics of two forage crops, maize and sorghum, frequently used by livestock enterprises, and their mixtures were evaluated without any additives. Results showed that to improve the nutritional and fermentation characteristics of silages, sorghum and maize may be ensilled as a mixture. On the other hand, it was highly recommended that silage additives should be used to guarantee and strengthen the fermentation and aerobic stability of silages mostly made by a mixture of these two energetic forage crops. 
Alhaag, H., Yuan, X., Mala, A., Bai, J., Shao, T. (2019). Fermentation characteristics of Lactobacillus plantarum and Pediococcus species isolated from sweet sorghum silage and their application as silage inoculants. Applied Sciences (Switzerland) 9(6):1247.

Anonymous. (1986). The analysis of agricultural material. Reference Book. P. 427-428, London, United Kingdom

AOAC. (1990). Official Methods of Analysis. 15th Edition. Association of Official Analytical Chemist, Washington DC

Ashbell, G. Z.G. Weinberg. A. Azrieli. Y. Hen. and B. Horev. (1991). A simple system to study the aerobic deterioration of silages. Canadian Agricultural Engineering 33. 391-393.

Başkavak, S., Özdüven, M.L., Polat, C., Koç, F. (2008). The effects of lactic acid bacteria+ enzyme mixture silage inoculant on wheat silage. Tekirdağ Ziraat Fakültesi Dergisi 5(3):291-296.

Büyüktosun, N., Tan, F. ( 2015).Farklı özelliklerdeki Polietilen Malzemelerin paket silajlarda kullanımı ve yem kalitesi üzerine etkileri. Tekirdağ Ziraat Fakültesi Dergisi 12(3):62-67.

Carvalho, W.G., Costa, K.A.D.P., Epifanio, P.S., Perim, R.C., Teixeira, D.A.A., Medeiros, L.T. (2016). Silage quality of corn and sorghum added with forage peanuts. Revista Caatinga 29 (2): 465-472

Chen, J., Stokes, M.R., Wallace, C.R. (1994). Effects of enzyme-inoculant systems on preservation and nutritive value of hay, crop and corn silages. Journal of Dairy Science 77: 501-512

Da Silva, T.C., Santos, E.M., Macedo, C.H.O., De Lima, M.A., Bezerra, H.F.C., Azevêdo, J.A.G., Rodrigues J.A.S., De Oliveira, J.S. (2012). Divergence of the fermentative and bromatological characteristics of 25 sorghum hybrid silages. Revista Brasileira de Zootecnia, 41(5): $1127-1133$

Daniel, B., Branislav, G., Miroslav, J., Milan, Š., Jaroslava, M., Erika, G., Michal, T. (2008). Fermentation process characteristics of different maize silage hybrids. Journal of Central European Agriculture 9 (3): 463-467

Demirel, M., Cengiz, F., Erdoğan, S., Çelik, S. (2003). Değişik oranlarda sudan otu ve macar fiğinden yapılan silajların kalitatif özellikleri ve rumende parçalanabilirlikleri üzerine bir araştırma. Turkish Journal of Veterinary and Animal Sciences 27 (4): 853-859

Dundar, M., Yucel, C., Unlu, M., Oluk, A. (2020). Çukurova Koşullarında Farklı Su Düzeylerinin Tatlı Sorgumun Biyokütle Verimine ve Yem Kalitesine Etkileri. Derim, 37 (1):86-94

Ferreira, G., Mertens, D.R. (2007) Measuring detergent fibre and in- soluble protein in corn silage using crucibles or filter bags. Animal Feed Science and Technology 133 (3-4):335-340

Filya, I., Sucu, E., Karabulut, A. (2004).The effect of Propionibacterium acidipropionici, with or without Lactobacillus plantarum, on the fermentation and aerobic stability of wheat, sorghum and maize silages. Journal of Applied Microbiology 97: 818-826

Gonçalves, J.R.S., Pires, A.V., Susin, I., Lima, L.G., Mendes, C.Q., Ferreira, E.M. (2010). Substituição do grão de milho pelo grão de milheto em dietas contendo silagem de milho ou silagem de capim- elefante na alimentação de bovinos de corte. Revista Brasileira de Zootecnia, 39 (9): 2032-2039

Kaewpila, C., Gunun, P., Kesorn, P., Subepang, S., Thip-Uten, S., Cai, Y.,Pholsen, S., Cherdthong, A., Khota, W. (2021). Improving ensiling characteristics by adding lactic acid bacteria modifies in vitro digestibility and methane production of forage-sorghum mixture silage. Scientific Reports, 11 (1):1-9.

Kaplan, M. (2013). The Effect of Variety on the Chemical Composition and Ensiling Characteristics of Sorghum Plant. KSU Journal of Agriculture and Nature 16 (2): 34-38

Kaplan, M., Kökten, K., Akçura, M. (2014). Determination of silage characteristics and nutritional values of some triticale genotypes. Turkish Journal of Agricultural and Natural Sciences 1(2): 102-107

Kaya, Ö., Polat, C. (2010). Tekirdağ ili koşullarında I. ve II. ürün olarak yetiştirilen bazı mısır çeşitlerinin silaj fermantasyon özellikleri ve yem değerinin belirlenmesi. Tekirdă̆ Ziraat Fakültesi Dergisi 7(3): 129-136.

Khota, W., Pholsen, S., Higgs, D. Cai, Y. (2017). Fermentation quality and in vitro methane production of sorghum silage prepared with cellulase and lactic acid bacteria. Asian-Australasian Journal of Animal Sciences 30:1568-1574

Kızılşimşek, M., Günaydın, T., Aslan A., Keklik, K., Açıkgöz, H. (2020). Improving Silage Feed Quality of Maize Intercropped with Some Legumes. Turkish Journal of Agricultural and Natural Sciences 7(1): 165-169

Koç, F., Coşkuntuna, L. (2003). The comparison of the two different methods on the determination of organic acids in silage fodders. Journal of Animal Production 44 (2): 37-47

Li, M., Shan, G., Zhou, H., Buescher, W., Maack, C., Jungbluth, K.H., Lipski, A., Grantz, D.A., Fan, Y., Ma, D., Wang, Z., Cheng, Q., Sun, Y. (2017). $\mathrm{CO}_{2}$ production, dissolution and pressure dynamics during silage production: multi-sensor-based insight into parameter interactions. Scientific Reports 7(1): 14721 
Liang, H., Zhang, J., Liu, G., Li, Y., You, Y., Zhao, H., Yang, Y., Fa, Y., Zhang, J., Zeng, B. (2018). Effects of mixed modes on fermentation quality and In vitro gas dynamics of sorghum-sudangrass hybrid (Sorghum bicolor $\times$ S. sudanense) silage. Semina: Ciências Agrárias 39 (6): $2807-2820$

Minitab. (2014). Minitab I: Statistical software for Windows, Release 17. Minitab Incorparation, USA

Moore, J.E., Undersander, D.J. (2002). Relative forage quality: An alternative to relative feed value and quality index. Proceedings 13th Annual Florida Ruminant Nutrition Symposium. 10-11 January, P. 16-29. Florida, USA.

Nakao, A.H., Andreotti, M., Soares, D.A., Modesto, V.C., Dickmann, L. (2018). Intercropping Urochloa brizantha and sorghum inoculated with Azospirillum brasilense for silage. Revista Ciencia Agronomica 49 (3): 501-511

Neto, A.B., Dos Reis, R.H.P., Da Silva Cabral, L., De Abreu, J.G., De Paula Sousa, D., Pedreira, B.C., Mombach, M.A., Balbinot, E., De Carvakho, P., Da Silva Carvalho, A.P. (2017). Fermentation characteristics of different purposes sorghum silage. Semina:Ciencias Agrarias 38 (4): 2607-2618

Neves, A.L.A., Santos, R.D., Pereira, L.G.R., Oliveira, G.F., Scherer, C.B., Verneque, R.S., McAllister, T. (2015). Agronomic characteristics, silage quality, intake and digestibility of five new Brazilian sorghum cultivars. Journal of Agricultural Science 153(2): 371-380

Nurk, L., Bühle, L., Wachendorf, M. (2016). Degradation of Fibre and Non-fibre Fractions During Anaerobic Digestion in Silages of Maize, Sunflower and Sorghum-Sudangrass of Different Maturities. Bioenergy Research 9 (3): 720-730.

Perazzo, A.F., De Carvalho, G.G.P., Santos, E.M., Pinho, R.M.A., Campos, F.S., Macedo, C.H.O., Azevêdo, J.A.G., Tabosa, J.N. (2014). Agronomic evaluation of 32 sorghum cultivars in the Brazilian semi-arid region. Revista Brasileira de Zootecnia 43 (5): 232-237

Pinho, R.M.A., Santos, E.M., De Oliveira, J.S., Bezerra, H.F.C., De Freitas, P.M.D., Perazzo, A.F., Da Silva Ramos, R.C., Da Silva, A.P.G. (2015). Sorghum cultivars of different purposes silage. Ciência Rural 45 (2): 298-303.

Rocateli, A.C., Raper, R.L., Balkcom, K.S., Arriaga, F.J., Bransby, D.I. (2012). Biomass sorghum production and components under different irrigation/tillage systems for the southeastern US. Industrial Crops and Products 36 (1): 589-598

Ruppel, K.A., Pitt, R.E., Chase, L.E., Galton, D.M. (1995). Bunker silo management and its relationship to forage preservation on dairy farms. Journal of Dairy Science 78: 141-153

Seale, D.R., Pahlow, G., Spoelstra, S.F., Lindgren, S., Dellaglio, F., Lowe, J.F. (1990). Methods for the microbiological analysis of silage. The Eurobac Conference. 12-16 August, P.147. Uppsala, Sweden.

Sucu, E., Kalkan, H., Canbolat, O., Filya, I. (2016). Effects of ensiling density on nutritive value of maize and sorghum silages. Revista Brasileira de Zootecnia 45 (10) 596-603.

Szymańska, G., Sulewska, H., Selwet, M. (2014). Hygienic condition of maize silage (Zea mays L.) depending on cutting height and ensiling additive. Turkish Journal of Agriculture and Forestry 38(3): 354-361

Tan, F. (2021).Laboratory type silage making Technique. Sustannable Agriculture And Livestock For Food Security Under The Changing Climate.

Toruk, F., Koç, F., Gönüol, E. (2010). Aerobik stabilite süresince paket silajlarında renk değişimi. Tekirdă̆ Ziraat Fakültesi Dergisi 7(1):2330.

Van Dyke, N.J., Anderson, P.M. (2002). Interpreting a forage analysis. Alabama Cooperative Extension, Circular ANR-890.

Van Soest, P.J., Robertson, J.B., Lewis, B.A. (1991). Methods for dietary fiber, neutral detergent fiber, and nonstarch polysaccharides in relation to animal nutrition. Journal of Dairy Science 1991 74: 3583-3597

Veriato, F.T., De Assis Pires, D.A., Tolentino, D.C., Alves, D.D., Jayme, D.G., Moura, M.M.A. (2018). Fermentation characteristics and nutritive values of sorghum silages. Acta Scientiarum - Animal Sciences 40, 1-9.

Vissers, M.M.M., Driehuis, F., Te Giffel, M.C., De Jong, P., Lankveld, J.M.G. (2007). Concentrations of butyric acid bacteria spores in silage and relationships with aerobic deterioration. Journal of Dairy Science 90: 928-936

Zurak, D., Grbeša, D., Kljak, K. (2018). Physical properties and fermentation profile of maize silage on large farms in Croatia. Journal of Central European Agriculture 19 (1): 126-141 